\title{
Impact of Low Fibrinogen Levels in the Puzzle of Trauma- induced Coagulopathy: Is This the Missing Link?
}

Juan C Duchesne, Chrissy Guidry, Timothy S Park, Eric Simms, Jordan RH Hoffman, Jiselle M Bock, Julie Wascom, James Barbeau, Peter Meade, Norman E McSwain Jr

\begin{abstract}
Background: Patients with severe tissue injury and tissue hypoperfusion can present with low fibrinogen levels and signs of hyperfibrinolysis. The role of damage control resuscitation (DCR) in addressing the hyperfibrinolytic aspect of trauma induced coagulopathy (TIC) is unknown. We hypothesize a survival advantage when DCR is used in TIC patients with severe tissue injury and low fibrinogen levels.
\end{abstract}

Materials and methods: This is a 2 years prospective observational study of TIC patients who received DCR. TIC was defined as initial base deficit $=-6$ in combination with ISS $=12$. Low fibrinogen was considered when serum level $<200$ $\mathrm{mg} / \mathrm{dl}$. Patients were stratified into those with an injury severity score $($ ISS $)<20$, and those with an ISS $=20$. Variables analyzed between groups included: initial serum fibrinogen, INR, base deficit, intraoperative FFP: PRBC ratio and mortality.

Results: Of 67 patients with TIC, 29 (43.2\%) had ISS < 20, and $38(56.7 \%)$ an ISS $\geq 20$. Mean ISS was 13.9 vs 32.8 ( $p<0.0001)$ for the ISS $<20$ group $v s$ the ISS $\geq 20$ group respectively. Mean initial fibrinogen levels for the ISS $<20$ group vs the ISS $\geq 20$ group was $357.4 \mathrm{mg} / \mathrm{dl}$ vs $148.5 \mathrm{mg} / \mathrm{dl}(\mathrm{p}=0.0007)$. Intraoperative DCR with FFP: PRBC for the ISS < 20 group vs the ISS $\geq 20$ group showed no statistical difference: 1 to $1.12 \mathrm{vs}$ 1 to $1.3(p=0.12)$. Overall mortality after controlling for DCR in the ISS $<20$ group was 29 and $73 \%$ in the ISS $\geq 20$ group ( $p=$ 0.0007 ). In a stepwise logistic regression, low fibrinogen levels was associated with mortality, $p=0.01$; OR 1.01 (1.23-11.55) with area under the receiver operating characteristic curve of 0.701 . The correlation coefficient for ISS vs initial fibrinogen level was $-0.5635(p=0.0001)$.

Conclusion: Overall mortality was significantly increased in patients who had an ISS $\geq 20$ with low fibrinogen level despite effective DCR. Given the correlated decrease in fibrinogen levels in patients with severe tissue injury, further investigation regarding potential benefits of antifibrinolytic agents in DCR needs further validation.

Keywords: Coagulopathy, Resuscitation, Fibrinogen, Fibrinolysis.

How to cite this article: Duchesne JC, Guidry C, Park TS, Simms E, Hoffman JRH, Bock JM, Wascom J, Barbeau J, Meade P, McSwain NE Jr. Impact of Low Fibrinogen Levels in the Puzzle of Trauma-induced Coagulopathy: Is This the Missing Link? Panam J Trauma Critical Care Emerg Surg 2013;2(2): 74-79.

\section{Source of support: Nil}

Conflict of interest: None declared

\section{RESUMEN}

Antecedentes: Los pacientes con graves lesiones en los tejidos y con baja perfusion pueden presentar con bajos niveles de fibrinógeno y signos de hyperfibrinolysis. La función de control de daños reanimación (DCR) para hacer frente a los hiperfibrinolisis aspecto de Trauma inducido coagulopatía (TIC) es desconocida. Nuestra hipótesis es una ventaja en la supervivencia cuando DCR se utiliza en TIC pacientes con graves lesiones en los tejidos y los bajos niveles de fibrinógeno.

Materiales y métodos: Este es un studio de 2 anos observacional prospectivo de los pacientes que recibieron TIC DCR. TIC se definió como base inicial déficit $=-6$ en combinación con ISS $=12$. Bajo fibrinógeno se consideró cuando nivel sérico $<200$ $\mathrm{mg} / \mathrm{dl}$. Los pacientes fueron estratificados en aquellos con un injury severity score (ISS) $<20$, y los que tienen un ISS $=20$. Las variables analizadas entre grupos incluyen: fibrinógeno sérico inicial, INR, déficit base, intra operatorio FFP: PRBC relación y mortalidad.

Resultados: De 67 pacientes con TIC, 29 (43,2 \%) había ISS < 20 , y $38(56,7 \%)$ con ISS $\geq 20$. ISS medio era de 13,9 frente a $32,8(p<0,0001)$ para ISS $<20$ grupo frente a la ISS $\geq 20$ grupo, respectivamente. Niveles de fibrinógeno promedio inicial del grupo con ISS $<20$ frente a ISS $\geq 20$ grupo fue $357,4 \mathrm{mg} / \mathrm{dl}$ vs $148,5 \mathrm{mg} / \mathrm{dL}$ ( $p=0,0007)$. Intra-operatoria DCR con FFP: PRBC para ISS $<20$ grupo frente a la ISS $\geq 20$ no mostró diferencia estadística: $1: 1.12$ vs 1:1.3 ( $p=0.12)$. Mortalidad general después de controlar DCR en ISS < 20 fue de 29 y $73 \%$ en ISS $\geq 20(p=0,0007)$. De forma gradual regresión logística, bajo niveles de fibrinógeno fue asociado con mortalidad, $p=0,01$; OR 1,01 (1.23 -11.55) con área bajo la curva de características del receptor operatorio de 0.701 . El coeficiente de correlación de ISS inicial vs fibrinogeno fue $-0.5635(p=0.0001)$.

Conclusiones: La mortalidad fue significativamente mayor en los pacientes que habían tenido un ISS $\geq 20$ con un bajo nivel de fibrinógeno a pesar de DCR. Habida cuenta de la correlación, disminución de niveles de fibrinógeno en pacientes con graves lesiones en los tejidos, más investigación acerca de los posibles beneficios de agentes antifibrinoliticos en DCR necesita validación adicional.

Palabras claves: Coagulopatía, Reanimación, Fibrinógeno, La fibrinólisis.

\section{INTRODUCTION}

Hemorrhage is one of the leading causes of preventable death in trauma. ${ }^{1}$ In patients with massive hemorrhage, damage control resuscitation (DCR) conveys a survival benefit with early intraoperative hemostatic resuscitation (IHR) when a close ratio of fresh frozen plasma (FFP) to pack red blood cells (PRBC) is achieved in combination with damage control surgery. ${ }^{2}$ A subset of this patients with severe hemorrhage will arrive to the emergency department with trauma induced coagulopathy (TIC). The etiology of this early coagulopathy associated with trauma is complex and directly associated with mortality. ${ }^{3}$ 
TIC develops in approximately $24 \%$ of patients independent of acidosis and hypothermia but secondary to trauma itself. ${ }^{4}$ TIC develops in the presence of severe tissue injury and tissue hypoperfusion causing a cascade of events leading to systemic anticoagulation and in a subset of patients, hyperfibrinolysis. ${ }^{5-9}$ Recently, the CRASH-2 trial looked at the effects upon mortality by using an antifibrinolytic, tranexaminic acid (TXA), which works by modulating the activation of plasmin..$^{10}$ TXA therefore inhibits clot breakdown, implying a favorable effect to patients with hemorrhage. ${ }^{10,11}$ Although, in their results TXA safely reduced mortality in bleeding trauma patients, the degree of injury severity and its correlation with DCR, degree of fibrinolysis and coagulopathy was not recorded. Our study investigates the impact of having low fibrinogen levels in TIC patients. We hypothesize a survival advantage when DCR is used in TIC patients with severe tissue injury and low fibrinogen levels.

\section{MATERIALS AND METHODS}

This was a 2-year IRB-approved prospective observational study from January 1 of 2009 until December 31 of 2010. All adult trauma patients with diagnosis of TIC upon presentation to our Level I Trauma Center requiring damage control surgery (DCS) along with DCR with $\geq 10$ units of PRBC over 24 hours were included. TIC was defined as an abnormal base deficit with ISS of $>12$. Once identified, patients were stratified into 2 groups based on their ISS: those with presenting ISS $<20$ were compared to those with ISS $\geq 20$. This delineation was based on evidence that presenting with an ISS $\geq 16$ is an independent risk factor for the development of acute traumatic coagulopathy ${ }^{11,12}$ and therefore a greater quantity of TIC patients. Once stratified, the means of serum fibrinogen concentration between groups were compared. Low fibrinogen concentration was considered when serum level $<200 \mathrm{mg} / \mathrm{dl}$.

DCR involved the utilization of a close-ratio FFP to PRBC with activation of massive transfusion protocol (MTP) that involved predetermined blood component transfusion ratios of 1:1 for FFP to PRBCs, and 1:2 for platelets (PLT) to PRBCs. Total transfused units of FFP, PRBC and PLT from initial presentation to the emergency department until 24 hours were recorded and a ratio for FFP to PRBC and PLT to PRBC calculated. DCR was accomplished in the context of DCS, which involved damage control laparotomy performed in the commonly described three-staged manner ${ }^{12}$ involving a truncated laparotomy, follow on physiologic optimization in the intensive care unit (ICU), and definitive organ management during a second operation.
Demographics compared between groups included: patient age (years), patient gender (male $v s$ female), mechanism of injury (blunt $v s$ penetrating), injury severity score (ISS) as defined by Baker et $\mathrm{a}^{15}$ and initial emergency department systolic blood pressure ( $\mathrm{mm} \mathrm{Hg}$ ). Comparison of laboratory values included serum fibrinogen concentration $(\mathrm{mg} / \mathrm{dl})$, activated partial thromboplastin time (aPTT; herein referred to as PTT), INR, calculated base deficit, and hemoglobin $(\mathrm{Hgb})$. This laboratory values were obtained at initial presentation to the emergency department, and approximately 6 hours afterward. Primary outcome of this study was to establish a correlation between ISS and serum fibrinogen concentration. Secondary endpoints included difference in mortality, ICU and hospital length of stay (LOS) between groups.

All statistical analyses were performed using MedCalc Version 10.2.0.0 (MedCalc Software, Mariakerke, Belgium). Logistic regression analysis utilized the stepwise method of independent variable input with a cut-off value of $p=$ 0.5 . Correlation coefficients were calculated as Pearson correlation coefficients.

\section{RESULTS}

During the 2-year study, a total of 67 trauma patients presented to the emergency department with diagnosis of TIC. There were 29 patients (43.2\%) with ISS $<20$ group and $38(56.7 \%)$ with ISS $\geq 20$ group. Mean age for each group ISS $<20 v s$ ISS $\geq 20$ was $33.3 v s 35.8(\mathrm{p}=0.78)$. Percent male gender for each group ISS $<20 v s$ ISS $\geq 20$ was $89.6 v s 92.1 \%(\mathrm{p}=0.62)$. Mean ISS for each group was calculated to be 13.9 for the ISS $<20$ group, and 32.8 for the ISS $\geq 20,(p<0.0001)$. Mechanism of injury comparing a percentage of penetrating:blunt in ISS $<20$ group $v s$ ISS $\geq 20$ was 72.4 vs $76.3 \%(\mathrm{p}=0.42)($ Table 1$)$.

\begin{tabular}{|l|l|l|l|}
\hline \multicolumn{5}{|c|}{ Table 1: Demographics } \\
\hline & ISS $<20$ & ISS $\geq 20$ & $p$-value \\
\hline $\mathrm{N}(\%)$ & $29(43.2)$ & $38(56.7)$ & \\
\hline Age (SD) & $33.3(11.9)$ & $35.8(15.0)$ & 0.78 \\
\hline Male gender & $89.6 \%$ & $92.1 \%$ & 0.62 \\
\hline Mean ISS (SD) & $13.9(5.1)$ & $32.8(10.5)$ & $0.0001^{*}$ \\
\hline Penetrating (\%) & $72.4 \%$ & $76.3 \%$ & 0.42 \\
\hline
\end{tabular}

Key: ISS—injury severity score; SD—standard deviation

Regarding intraoperative hemostatic DCR between groups, total transfused units of PRBC in the ISS $<20$ group $v s$ ISS $\geq 20$ group was $26.0 \pm 22.1 v s 20.5 \pm 18.2$; total transfused FFP units was $22.3 \pm 19.6$ vs $15.6 \pm 16.2$; and total transfused PLT was $10.1 \pm 6.9$ vs $6.7 \pm 6.4$. The mean PRBC-to-FFP ratio comparing ISS $<20 v s$ ISS $\geq 20$ was $1: 1.12$ vs $1: 1.3(\mathrm{p}=0.12)$. 
Impact of Low Fibrinogen Levels in the Puzzle of Trauma-induced Coagulopathy: Is This the Missing Link?

Initial laboratory analysis of the ISS $<20$ group $v s$ ISS $\geq$ 20 group, patients presented with a mean PTT of $32.9 \pm 18.2$ seconds $v s 55.4 \pm 43.2$ seconds $(\mathrm{p}=0.013)$, a hemoglobin of $10.8 \pm 2.5$ vs $9.8 \pm 1.9(\mathrm{p}=0.08)$, a mean INR of $1.2 \pm$ $0.2 v s 1.8 \pm 1.4(\mathrm{p}=0.049)$, and a base excess of $-3.0 \pm 6.0$ $v s-3.6 \pm 5.0(\mathrm{p}=0.742)$. Patients with ISS $<20$ vs ISS $\geq$ 20 presented with a mean initial fibrinogen of $357.4 \pm 49.1$ $\mathrm{mg} / \mathrm{dl}$ vs $150.8 \pm 47.1 \mathrm{mg} / \mathrm{dl}(\mathrm{p}=0.0001)$ (Table 2 and Fig. 1$)$.

\begin{tabular}{|l|l|l|l|}
\hline \multicolumn{4}{|c|}{ Table 2: Laboratory analysis, initial presentation } \\
\hline & ISS $<20$ & ISS $\geq 20$ & $p$-value \\
\hline PTT (SD) & $32.9(18.2)$ & $55.4(43.2)$ & $0.013^{*}$ \\
\hline Hgb (SD) & $10.8(2.5)$ & $9.8(1.9)$ & 0.08 \\
\hline INR (SD) & $1.2(0.2)$ & $1.8(1.4)$ & $0.049^{*}$ \\
\hline Base deficit (SD) & $-3.0(6.0)$ & $-3.6(5.0)$ & 0.742 \\
\hline Fibrinogen (SD) & $357.4(49.1)$ & $150.8(47.1)$ & $0.0001^{*}$ \\
\hline
\end{tabular}

Key: PTT—partial thromboplastin; Hbg-hemoglobin; INRinternational normalized ratio; SD—standard deviation

Additional laboratory values were again analyzed 6 hours after arrival. In an analysis of ISS $<20$ group $v s$ ISS $\geq 20$ group, patients had PTT $30.7 \pm 9.1$ vs $45.0 \pm 18.3$ $(\mathrm{p}=0.001)$, hemoglobin $11.4 \pm 3.6$ vs $9.5 \pm 2.6(\mathrm{p}=0.06)$, INR $1.3 \pm 0.3 v s 1.6 \pm 1.5(\mathrm{p}=0.34)$, and base excess -0.5 \pm 3.0 vs $0.6 \pm 6.2(\mathrm{p}=0.16)$. Serum fibrinogen 6 hours after presentation in ISS $<20 v s$ ISS $\geq 20$ was $246.75 \pm 112.54$ vs $276.3 \pm 135.8(\mathrm{p}=0.07)($ Table 3$)$.

\begin{tabular}{|l|l|l|l|}
\hline \multicolumn{4}{|c|}{ Table 3: Laboratory analysis, 6 hours postinjury } \\
\hline & ISS $<20$ & ISS $\geq 20$ & $p$-value \\
\hline PTT (SD) & $30.7(9.1)$ & $45.0(18.3)$ & $0.001^{*}$ \\
\hline Hgb (SD) & $11.4(3.6)$ & $9.5(2.6)$ & 0.06 \\
\hline INR (SD) & $1.3(0.3)$ & $1.6(1.5)$ & 0.34 \\
\hline Base deficit (SD) & $-0.5(3.0)$ & $0.6(6.2)$ & 0.16 \\
\hline Fibrinogen (SD) & $246.75(112.54)$ & $150.8(47.1)$ & 0.07 \\
\hline
\end{tabular}

Key: PTT—partial thromboplastin; Hgb—hemoglobin; INRinternational normalized ratio; SD—standard deviation

Calculation of Pearson product-moment coefficient for PTT, INR and base excess vs ISS showed no linear correlation between ISS and PTT $(r=-0.027, p=0.832)$, ISS and INR ( $r=-0.009, p=0.946)$, or base excess and ISS $(r=-0.093, p=0.464)$. Calculation of the Pearson productmoment correlation coefficient for initial serum fibrinogen levels $v s$ ISS yielded a value of -0.5635 with $\mathrm{p}=0.0001$.

A stepwise logistic regression evaluating the presenting initial variables of PT, INR, Hgb, calculated base excess and serum fibrinogen concentration found that of these, only initial fibrinogen levels were associated with mortality, having a significance level of $p<0.0001$ (Graph 1). The resulting model yielded an odds ratio of $1.01 \pm 0.087$, an area under the receiver operating characteristic curve of 0.701 . After DCR, patients with normal initial fibrinogen levels and ISS $<20$ had an overall mortality of $29 \%$, compared to

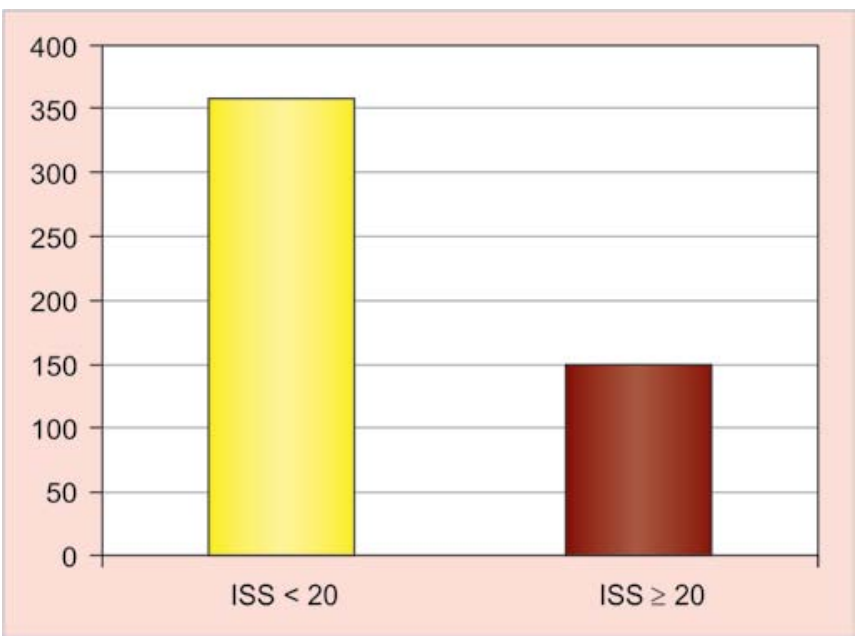

Graph 1: Fibrinogen level on arrival (Note: Fibrinogen levels compared between the two groups on arrival to the ED. ISS $<20$ group ISS vs ISS $\geq 20$ was $357.4 \pm 49.1 \mathrm{mg} / \mathrm{dl}$ vs $150.8 \pm 47.1 \mathrm{mg} /$ $\mathrm{dl}(\mathrm{p}=0.0001)$

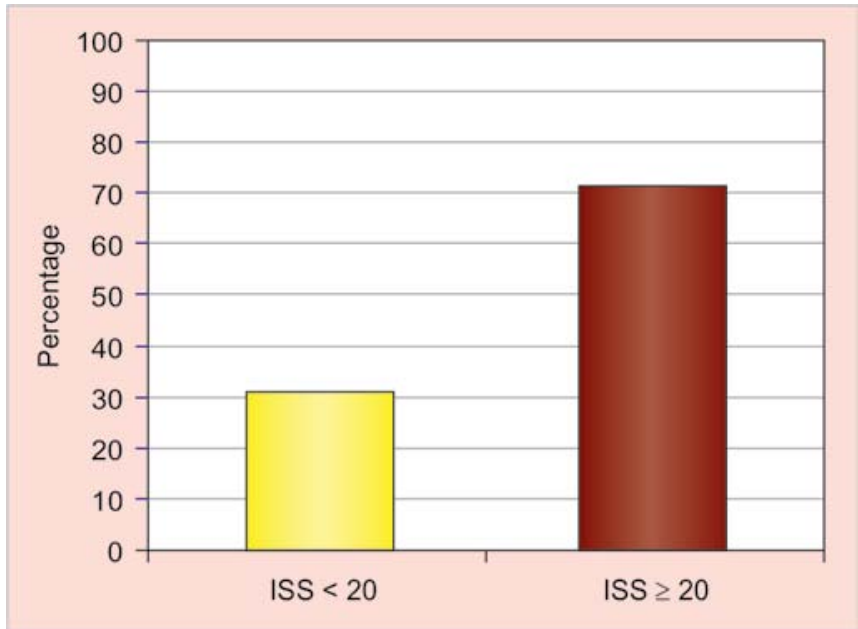

Fig. 2: Linear regression analyzing mortality [Note: Overall mortality for patients with ISS $<20$ and normal initial fibrinogen level vs ISS $\geq 20$ with low initial fibrinogen level was 29 vs $73 \%(p=0.0007)]$.

those with low initial fibrinogen levels and ISS $\geq 20$ with $73 \%$ overall mortality $(\mathrm{p}=0.0007)($ Graph 2$)$.

\section{DISCUSSION}

Management of patients presenting with severe tissue injury and TIC remain clinically important. More severely injured trauma patients present with a greater degree of coagulopathy. ${ }^{4,5}$ This coagulopathy was demonstrated in our study with an abnormally high PTT/INR as well as a low initial serum fibrinogen concentration seen in patients with higher ISS. Initial serum fibrinogen was discovered to have a correlating inverse relationship with degree of injury and mortality. Better understanding and recognition of the significance of low fibrinogen levels could help improve future therapies toward the management of hyperfibrinolysis. 


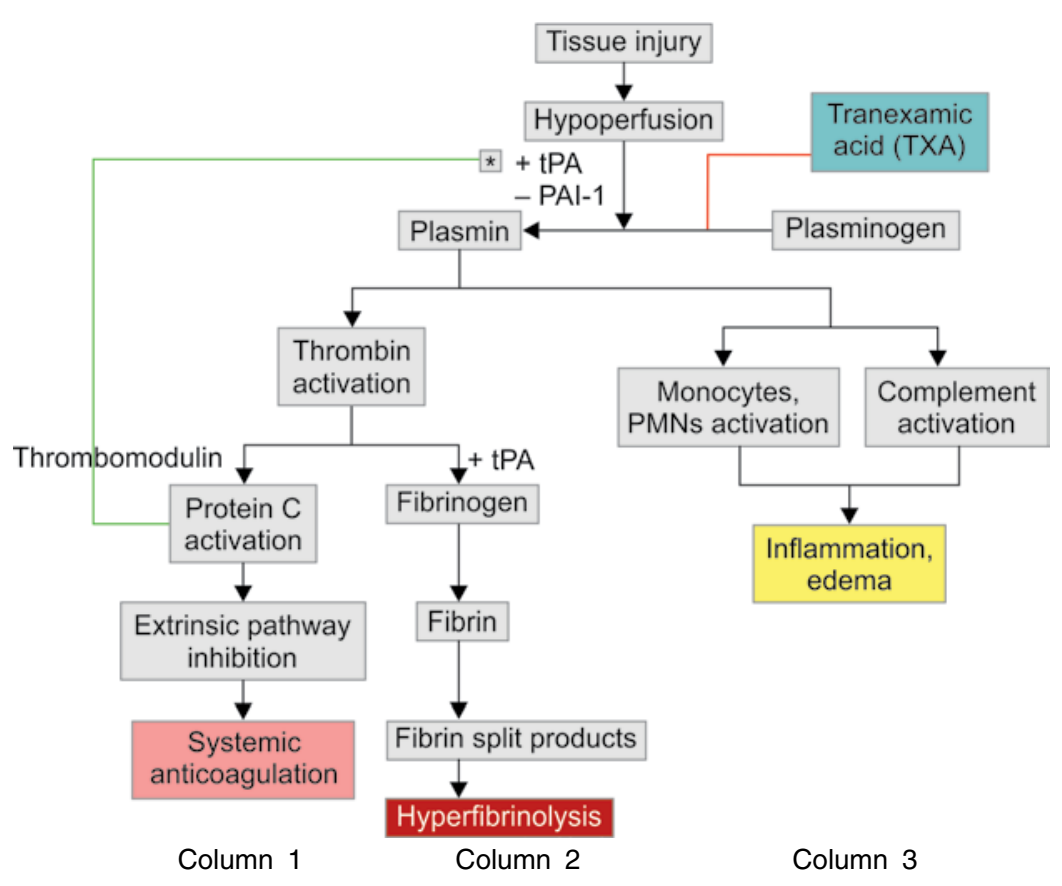

Flow Chart 1: Proposed mechanism of action of TXA in patients with trauma induced coagulopathy [Note: Following severe tissue injury and hypoperfusion, a cascade of events is proposed. Tissue plasminogen activator (tPA) is released following severe tissue injury to initiate coagulopathy and inflammation. Protein $\mathrm{C}$ activation inhibits the extrinsic pathway and further systemic anticoagulation, column \#1; Protein $\mathrm{C}$ activation further *acts to inhibit plasminogen activator inhibitor-1 (PAl-1) and allow for further tPA activation of fibrinolysis, resulting in a hyperfibrinolytic state, column \#2. The additional arm of the cascade (column \#3) depicts the proposed inflammatory endpoints, outside of the hemostatic component. Role of tranexamic acid (TXA) in this cascade can be multifactorial. Better understanding on its antihyperfibrinolytic and anti-inflammatory properties needs further validation]

The mechanism for the development for hyperfibrinolysis involves the release of tissue plasminogen activator (tPA) and kallikrein-mediated plasmin activators following tissue injury. ${ }^{16}$ In part of a hemostatic balance, multiple inhibitors are also generated which include plasminogen activator inhibitor 1 (PAI-1), thrombin-activatable fibrinolysis inhibitor (TAFI), and $\alpha_{2}$-antiplasmin. ${ }^{17,18}$ Protein $\mathrm{C}$ is activated by thrombomodulin (TM) following injury and is also believed to promote release of tPA by consuming PAI-1, further activating plasminogen. ${ }^{4,5}$ Activation of plasminogen increases fibrinolysis, cleavage of fibrinogen to fibrin, resulting in a hyperfibrinolytic state (Flow Chart 1, columns 1 and 2).

Serum fibrinogen levels can also be affected by volume resuscitation strategies, acidemia, platelet interaction, and hypothermia. During volume replacement, the effect is primarily that of dilution, ${ }^{19}$ although hydroxyethyl starch solutions may directly cause impaired fibrin polymerization. ${ }^{20}$ Regarding production and breakdown of serum fibrinogen, acidemia increases fibrinogen breakdown with no effect on synthesis ${ }^{21}$ while hypothermia to $32^{\circ} \mathrm{C}$ decreases synthesis of fibrinogen. ${ }^{22}$ As a multitude of cellular events occur after trauma, coagulopathy and bleeding worsen due to a dysregulated hemostatic balance postinjury. ${ }^{23}$
Low fibrinogen serum levels were recorded at initial presentation in the ISS $\geq 20$ group. Although these low fibrinogen levels normalized after DCR at 6 hours postpresentation, patients with ISS $\geq 20$ had an overall higher mortality. Although the amount cryoprecipitate was not recorded in this study patients with ISS $\geq 20$ received an average of 15.6 units of FFP during DCR yielding approximately $150 \mathrm{mg} / \mathrm{dl}$ of fibrinogen for a $70 \mathrm{~kg}$ individual. A normal, unstressed individual produces fibrinogen at an absolute synthesis rate of about $1.5 \mathrm{mg} /$ $\mathrm{dl} / \mathrm{h},{ }^{24-26}$ yielding approximately $9 \mathrm{mg} / \mathrm{dl}$ replenished over 6 hours. Therefore, the increase of serum fibrinogen levels 6 hours after presentation in the ISS $\geq 20$ group is likely primarily due to effective DCR rather than patients' own physiologic replenishment. Even though fibrinogen levels increased 6 hours after injury with DCR, the initial low fibrinogen level was a better predictor of mortality in patients with high ISS. Our study demonstrates that perhaps an adjunct to DCR is needed to decrease mortality in trauma patients with observed low fibrinogen levels seen with TIC.

The CRASH-2 trial prospectively addressed the effects of the hyperfibrinolysis through the pharmacologic inhibition of the activation of plasminogen to plasmin with tranexamic acid (TXA). Their results showed a decrease in all-cause 
and bleeding-related mortality by $1.5 \% .^{10}$ Of notice in the CRASH-2 study, the degree of fibrinolysis was not quantified with laboratory findings and TXA was administered, if hemorrhage was clinically suspected, not necessarily proven. In a recent retrospective military study, MATTERs, patients requiring massive transfusion demonstrated a decrease in mortality when TXA was used in combination with component based therapy. They demonstrated an absolute reduction in in-hospital mortality of $13.7 \%$ and overall better 30 -day survival. ${ }^{28}$ They also demonstrated an improvement in the coagulopathy profile when TXA was used. It is important to note that the patients that did not received TXA and those that did receive TXA had an overall similar component-based resuscitation, indicating a pharmacological role in improving coagulopathy.

With findings from CRASH-2 and MATTERs, it could then be hypothesized that rapid correction of serum fibrinogen concentrations and its resultant role in clot stabilization, addressing TIC-related hyperfibrinolysis, plays a role in the survival benefit of DCR. Interestingly, an additional survival benefit was demonstrated in the MATTERs study after 48 hours, after surviving exsanguinating injuries. They conclude that TXA may have an additional protective role in the attenuation of inflammation, in addition to improving the coagulation profile ${ }^{28}$ (Flow Chart 1). Future prospective trials should focus in investigating the optimal resuscitation strategy consisting of component therapy in addition to antifibrinolytics pharmacotherapy in patients with severe tissue injury and low initial fibrinogen levels.

\section{CONCLUSION}

In our study, patients with severe tissue injury presented with below normal initial serum fibrinogen concentrations. Overall mortality was significantly increased in patients who had an ISS $\geq 20$ with low initial fibrinogen level despite effective DCR. A decrease in this initial serum fibrinogen correlated with increased mortality even when other initial measures of coagulopathy, such as PTT and INR may not. Given the correlated decrease in fibrinogen levels in patients with severe tissue injury, further investigation regarding potential benefits of antifibrinolytic agents in DCR is warranted.

\section{REFERENCES}

1. Tieu BH, Holcomb JB, Schreiber MA. Coagulopathy: its pathophysiology and treatment in the injured patient. World $\mathrm{J}$ Surg 2007;31(5):1055-1064.

2. Duchesne JC, McSwain NE, Cotton BA, et al. Damage control resuscitation: the new face of damage control. J Trauma 2010;69(4):976-990.
3. MacLeod JBA, Lynn M, McKenney MG, Cohn SM, et al. Early coagulopathy predicts mortality in trauma. J Trauma 2003;55(1):39-44.

4. Brohi K, Singh J, Heron M, et al. Acute traumatic coagulopathy. J Trauma 2003;54(6):1127-1130.

5. Brohi K, Cohen MJ, Davenport RA. Acute coagulopathy of trauma: mechanism, identification and effect. Curr Opin Crit Care 2007 Dec;13(6):680-685.

6. Fries D, Martini WZ. Role of fibrinogen in trauma-induced coagulopathy. Br J Anaesth 2010;105(2):116 -121.

7. Holcomb JB, Jenkins D, Rhee P, et al. Damage control resuscitation: directly addressing the early coagulopathy of trauma. J Trauma 2007;62(2):307-310.

8. Jansen JO, Thomas R, Loudon MA, et al. Damage control resuscitation for patients with major trauma. BMJ 2009; 338:b1778.

9. Duchesne JC, Islam TM, Stuke L, et al. Hemostatic resuscitation during surgery improves survival in patients with traumaticinduced coagulopathy. J Trauma 2008;67(1):33-39.

10. CRASH-2 trial collaborators. Effects of tranexamic acid on death, vascular occlusive events, and blood transfusion in trauma patients with significant haemorrhage (CRASH-2): a randomised, placebo-controlled trial. Lancet 2010;376(9734):23-32.

11. Cohen MJ, Brohi K, Ganter MT, et al. Early coagulopathy after traumatic brain injury: the role of hypoperfusion and the protein C pathway. J Trauma 2007;63(6):1254-1261; discussion 12611262.

12. Duchesne JC, Holcomb JB. Damage control resuscitation: addressing trauma-induced coagulopathy. Br J Hosp Med (Lond) 2009;70(1):22-25.

13. Maegele M. Frequency, risk stratification and therapeutic management of acute post-traumatic coagulopathy. Vox Sang 2009;97(1):39-49.

14. Talving P, Benfield R, Hadjizacharia P, et al. Coagulopathy in severe traumatic brain injury: a prospective study. J Trauma 2009;66(1):55-61; discussion 61-62.

15. Baker SP, O'Neill B. The injury severity score: an update. J Trauma 1976;16(11):882-885.

16. Schöchl H, Frietsch T, Pavelka M, et al. Hyperfibrinolysis after major trauma: differential diagnosis of lysis patterns and prognostic value of thrombo-elastometry. J Trauma 2009;67(1):125-131.

17. Kashuk JL, Moore EE, Sawyer M, et al. Primary fibrinolysis is integral in the pathogenesis of the acute coagulopathy of trauma. An Surg 2010;252: 434-444.

18. Medcalf RL. Fibrinolysis, inflammation, and regulation of the plasminogen activating system. J Thromb Haemost 2007;5 (Suppl 1): 132-142.

19. Martini WZ, Chinkes DL, Sondeen J, et al. Effects of hemorrhage and lactated Ringer's resuscitation on coagulation and fibrinogen metabolism in swine. Shock 2006;26(4):396-401.

20. Mittermayr M, Streif W, Haas T, et al. Hemostatic changes after crystalloid or colloid fluid administration during major orthopedic surgery: the role of fibrinogen administration. Anesth. Analg 2007;105(4):905-917.

21. Martini WZ, Holcomb JB. Acidosis and coagulopathy: the differential effects on fibrinogen synthesis and breakdown in pigs. Ann Surg 2007;246(5):831-835.

22. Martini WZ, Pusateri AE, Uscilowicz JM, et al. Independent contributions of hypothermia and acidosis to coagulopathy in swine. J Trauma 2005;58(5):1002-1009; discussion 1009-1010. 
23. Levy JH, Dutton RP, Hemphill JC, et al. Multidisciplinary approach to the challenge of hemostasis. Anesth Analg 2010; 110: 354-364.

24. Stein T, Mullen J, Oram-Smith J, et al. Relative rates of tumor, normal gut, liver and fibrinogen protein synthesis in man. Am J Physiol - Endocrinol and Metabolism 1978;234(6):E648 -E652.

25. Tessari P, Kiwanuka E, Millioni R, et al. Albumin and fibrinogen synthesis and insulin effect in type 2 diabetic patients with normoal buminuria. Diabetes Care 2006;29(2):323-328.

26. Prinsen BHCMT, Rabelink TJ, Beutler JJ, et al. Increased albumin and fibrinogen synthesis rate in patients with chronic renal failure. Kidney Int 2003;64(4):1495-1504.

27. Morrison JJ, Dubose JJ, Rasmussen TE, et al. Military Application of Tranexamic acid in Trauma Emergency Resuscitation (MATTERs) Study. Arch Srug 2012 Feb; 147(2): 113-119.

\section{ABOUT THE AUTHORS}

\section{Juan C Duchesne (Corresponding Author)}

Director of Surgical Intensive Care Unit, Section of Trauma and Critical Care Surgery, Department of Surgery and Anesthesia, Tulane University School of Medicine, 1430 Tulane Ave, SL-22, New Orleans, LA 70112-2699, USA, Phone: 504-988-5111, Fax: 504-988-3683, e-mail: jduchesn@tulane.edu

\section{Chrissy Guidry}

Department of Surgery, Tulane University, School of Medicine, New Orleans, LA, USA

\section{Timothy S Park}

Department of Surgery, Tulane University, School of Medicine, New Orleans, LA, USA

\section{Eric Simms}

Department of Surgery, Tulane University, School of Medicine, New Orleans, LA, USA

\section{Jordan RH Hoffman}

Department of Surgery, Tulane University, School of Medicine, New Orleans, LA, USA

\section{Jiselle M Bock}

Department of Surgery, Tulane University, School of Medicine, New Orleans, LA, USA

\section{Julie Wascom}

Department of Surgery, Tulane University, School of Medicine, New Orleans, LA, USA

\section{James Barbeau}

Department of Surgery, Tulane University, School of Medicine, New Orleans, LA, USA

\section{Peter Meade}

Department of Surgery, Tulane University, School of Medicine, New Orleans, LA, USA

\section{Norman E McSwain Jr}

Department of Surgery, Tulane University, School of Medicine, New Orleans, LA, USA 